\begin{tabular}{|l|l|l|l|l|l|} 
J. Tek. Ling & Vol.11 & No.3 & Hal. 443 - 449 & Jakarta, September 2010 & ISSN 1441-318X \\
\hline
\end{tabular}

\title{
PROFIL PERUBAHAN AMONIUM, NITRIT DAN NITRAT PADA PERCOBAAN CURAH DARI PDAM BOGOR DAN SURABAYA
}

\author{
Hartati Imamuddin \\ Peneliti di Pusat Penelitian Biologi - LIPI \\ JI.Raya Jakarta-Cibinong KM 46 Cibinong
}

\begin{abstract}
Nitrification is often not effective because the characters of nitrifying bacteria is always slow growing and temperature, $\mathrm{pH}, \mathrm{DO}$, amonia concentration, nitrite and $\mathrm{C} / \mathrm{N}$ ratio as the limited factors. Batch experiment was operated for 6 hours, every half an hours ammonium, nitrite and nitrate were measured.

The results showed that added $C$ sourse (glucose) in medium from PDAM Bogor and Surabaya have a significant effects of ammonium degradation, nitrite and nitrate production.

Degradation of ammonium in batch reactor from PDAM Bogor showed that both anaerobic and aerobic condition have a different fluctuation. Production of nitrite was stable from the middle of reaction to last of aerobic phase. In aerobic condition nitrate production is reduced to $49,21 \%$ (+ glucose) and 60,87\% (+ acetate)

Batch reactor from PDAM Surabaya differ from PDAM Bogor particularly on degradation of ammonium. Added glucose as $C$ source cause the concentration of ammonium was increased and acetate as $C$ source showed stable with a slightly fluctuation. Nitrite and nitrate production relatively small in both $C$ source.
\end{abstract}

\section{PENDAHULUAN}

\subsection{Latar Belakang}

Perombakan amonia secara sempurna berlangsung dalam dua tahapan yaitu, amonia menjadi nitrat (nitrifikasi) dan nitrat menjadi $\mathrm{N}_{2}$ gas (denitrifikasi) ${ }^{1)}$. Didalam sistem biologis, nitrifikasi seringkali tidak efektif, karena sifat pertumbuhan bakteri nitrifikasi sangat lambat dan sensitif terhadap faktor-faktor lingkungan, seperti suhu, $\mathrm{pH}$, konsentrasi oksigen terlarut (DO), konsentrasi amonia, nitrit dan rasio $\mathrm{C} / \mathrm{N}$.

Bakteri yang berperan dalam proses nitrifikasi dan telah banyak dipelajari adalah Nitrosomonas dan Nitrobacter. Akhir-akhir ini dilaporkan bahwa kelompok bakteri lain seperti Nitrospira, Nitrosococcus merupakan bakteri lain yang mampu melakukan perombakan amonium.

Oksidasi amonia merupakan reaksi pembatas pada proses peruraian nitrogen didalam pengolahan limbah cair. Kuantifikasi hubungan antara kecepatan oksidasi amonia dengan konsentrasi amonia dengan konsentrasi $\mathrm{NH}_{4}^{+}$didalam campuran cairan harus dipertimbangkan untuk keberhasilan desain dan operasi unit pengolahan limbah.

Penghambatan substrat dari oksidasi amonia telah diketahui/dipelajari dalam 
berbagai penelitian menggunakan lumpur aktif. Telah dilaporkan juga konsentrasi yang rendah dari amonia bebas $(<1 \mathrm{mM})$ toksik terhadap oksidasi amonia ${ }^{2)}$

\subsection{Tujuan}

Tujuan penelitian adalah untuk mengetahui pengaruh nutrient dan macam sumber lumpur aktif yang berbeda terhadap profil amonium, nitrit dan nitrat.

\section{METODOLOGI}

\subsection{Bahan}

\section{1) Lumpur Aktif yang digunakan}

Lumpur aktif diambil dari UPL yang mengolah air minum di Bogor dan Surabaya yang menerapkan sistim anaerobik-aerobik. Lumpur aktif yang diambil berasal dari akhir fase aerob

2) Media yang digunakan untuk mengaklimasi Lumpur aktif dengan komposisi sebagai berikut : 2.5 gram Glukosa dan 2.5 gram Na Asetat sebagai sumber karbon, 0.5 gram $\left(\mathrm{NH}_{4}\right.$ )$_{2} \mathrm{SO}_{4}$ dan 0.5 gram ekstrak khamir sebagai sumber $\mathrm{N}, 0.25$ gram $\mathrm{KH}_{2} \mathrm{PO}_{4}$ dan 0.25 gram $\mathrm{K}_{2} \mathrm{HPO}_{4}$ sebagai sumber $\mathrm{P}$, dan sebagai sumber alkali digunakan 0.1 gram $\mathrm{KCl}, 0.1$ gram $\mathrm{FeCl}_{3}, 0.1$ gram $\mathrm{CaCl}_{2}$ dan $\mathrm{MnSO}_{4}$.

Nutrient yang digunakan untuk sumber C PDAM Surabaya sebanyak $250 \mathrm{mg} / \mathrm{L}$ sumber $C$ berasal dari Sukrosa $=333,24$ $\mathrm{mg} / \mathrm{l}$ dan Glukosa $=250 \mathrm{mg} / \mathrm{L}$ dengan perbandingan $6: 4$, sumber $\mathrm{N}$ sebanyak $125 \mathrm{mg}=589,28 \mathrm{mg} / \mathrm{L}\left(\mathrm{NH}_{4}\right)_{2} \mathrm{SO}_{4}$ sebagai sumber $\mathrm{P} 2,5 \mathrm{mg}=10,96 \mathrm{mg} / \mathrm{L}$ berasal dari $\mathrm{KH}_{2} \mathrm{PO}_{4}$ dan sebagai sumber alkali 0,25 $\mathrm{mg}=2,56 \mathrm{mg} / \mathrm{L} \mathrm{Mg}\left(\mathrm{MgSO}_{4} \cdot 7 \mathrm{H}_{2} \mathrm{O}\right), 0,25 \mathrm{mg}$ $\mathrm{Ca}=0,91 \mathrm{mg} / \mathrm{L}\left(\mathrm{CaCl}_{2} \cdot 2 \mathrm{H}_{2} \mathrm{O}\right)$. Sedangkan untuk PDAM Bogor pada kondisi anaerobik ditambahkan :10 ml dari campuran $\left(\mathrm{NH}_{4}\right)_{2} \mathrm{SO}_{4}$
$=58,9 \mathrm{mg} / \mathrm{l}, \mathrm{KH}_{2} \mathrm{PO}_{4}=10,9 \mathrm{mg} / \mathrm{l}$, glucose $=$ $375 \mathrm{mg} / \mathrm{l}$, Natrium acetat $=342 \mathrm{mg} / \mathrm{l}, \mathrm{MgSO}_{4}$ $=2,5 \mathrm{mg} / \mathrm{l}, \mathrm{CaCl}_{2} 2 \mathrm{H}_{2} \mathrm{O}=9.19 \mathrm{mg} / \mathrm{l}$.

\section{3) Metoda aklimatisasi}

$50 \mathrm{ml}$ lumpur aktif ditambahkan pada 1 liter media. Inkubasi dilakukan dengan sistem aerobik selama 1 minggu, kemudian dihitung MLSSnya (MLSS > 3000) diteruskan secara aerobik dan anaerobic dengan selang waktu satu hari. Pemberian makan dilakukan pada saat akan memasuki periode anaerob. Analisa perubahan ammonium, nitrit dan nitrat dilakukan bersamaan dengan analisa glikogen dan pelepasan fosfat oleh komunitas bakteri dilakukan setelah 3 bulan aklimatisasi.

\section{4) Parameter yang diamati}

Pada percobaan curah (batch experiment) PDAM Bogor dan Surabaya dilakukan pengukuran amonium, produksi nitrit dan nitrat

\section{HASIL DAN PEMBAHASAAN}

\subsection{Produksi nitrat, nitrit dan amonium disajikan pada tabel 1}

Tabel 1. Produksi nitrat, nitrit dan amonium dalam batch reaktor dengan percobaan curah selama 6 jam reaksi dengan sumber karbon (C) utama glukosa dan asetat dari limbah PDAM Bogor.

Pada saat anaerob proses denitrifikasi dengan sumber $\mathrm{C}$ utama glukosa dan Asetat (PDAM Bogor) berjalan tidak stabil, dan terjadi akumulasi nitrit pada 2,5 jam reaksi sampai mencapai 518,739 mg/l, hasil ini nampaknya hampir sama dengan percobaan ${ }^{3)}$ Bovell, 1987 yang menggunakan Pseudomonas perfectomarinus, dimana terjadi akumulasi nitrit pada saat awal periode anarobik sebelum pelepasan gas ( 6 jam reaksi) dan turun setelah 10 jam reaksi. Ketidakstabilan ini bisa juga diakibatkan oleh ketersediaan oksigen dalam 
media, temperature yang selalu berubah dan $\mathrm{pH}$ yang relatif asam $(<6)$ akan sangat berpengaruh pada proses denitrifikasi. Faktor pembatas yang paling berperan dalam proses denitrifikasi adalah temperatur. Pengaruh temperatur dan lamanya inkubasi sangat berpengaruh pada laju denitrifikasi pernah didemontrasikan oleh Focht, 19774). Pada saat awal proses aerobik amonium masih stabil tidak ada perubahan demikian juga untuk produksi nitrit, tetapi nampaknya hanya nitrat yang terlihat turun dan kemudian stabil. Pada 2 jam produksi nitrit turun baik pada percobaan 1 maupun 2.

Perlu ditambahkan dengan terbentuknya produksi nitrit dan nitrat yang tinggi dimungkinkan bakteri yang berperan adalah heterotropik nitrifier, karena bakteri tersebut cenderung tumbuh lebih cepat dan relatif tahan terhadap $\mathrm{pH}$ asam $(<7) .{ }^{5}$

Table1. Produksi nitrat, nitrit dan amonium dalam batch reaktor dengan percobaan curah selama 6 jam reaksi dengan sumber karbon (C) utama glukosa dan asetat dari limbah PDAM Bogor

\begin{tabular}{|l|l|l|l|l|l|l|l|l|}
\hline & & Glukosa & & & Asetat & & & \\
\hline Waktu & Nitrat & \multicolumn{1}{|c|}{ Nitrit } & Ammonium & \multicolumn{1}{|c|}{ Nitrat } & Nitrit & Ammonium & Glucose & pH \\
\hline 0 & - & 11,942 & 39,548 & 6.74 & 46.448 & 31.487 & 252,5 & 5,486 \\
\hline 30 & 84,853 & 447,922 & 23,007 & 71.962 & 755.431 & 25.134 & 236,5 & 5,363 \\
\hline 60 & 92,131 & 459,251 & 40,682 & 93.832 & 147.541 & 39.689 & 257,5 & 5,332 \\
\hline 90 & 86,400 & 298,207 & 37,374 & 85.862 & 23.017 & 39.831 & 211,5 & 5,347 \\
\hline 120 & 95,334 & 386,135 & 46,607 & 89.862 & 503.53 & 43.376 & 162,5 & 5,306 \\
\hline 150 & 99,976 & 518,739 & 11,429 & 94.305 & 302.756 & 11.901 & 146,5 & 5,673 \\
\hline 180 & 106,97 & 398,967 & 44,085 & 115.447 & 181.762 & 38.981 & 126,5 & 5,254 \\
\hline 30 & 54,325 & 303,435 & 42,998 & 45.165 & 456.001 & 36.193 & - & 5,609 \\
\hline 60 & 55,579 & 344,789 & 49,047 & 63.474 & 474.538 & 35.626 & 78,5 & 5,329 \\
\hline 90 & 56,097 & 420,830 & 40,068 & 58.626 & 435.565 & 34.019 & 82,5 & 5,382 \\
\hline 120 & 61,582 & 191,743 & 42,478 & 63.569 & 178.91 & 38.319 & 80,5 & 5,355 \\
\hline 150 & 55,421 & 402,769 & 97,582 & 79.919 & 373.302 & 73.338 & 66,5 & 5,300 \\
\hline 180 & 51,033 & 347,636 & 68,045 & 68.417 & 243.074 & 68.896 & 72,5 & 5,388 \\
\hline
\end{tabular}

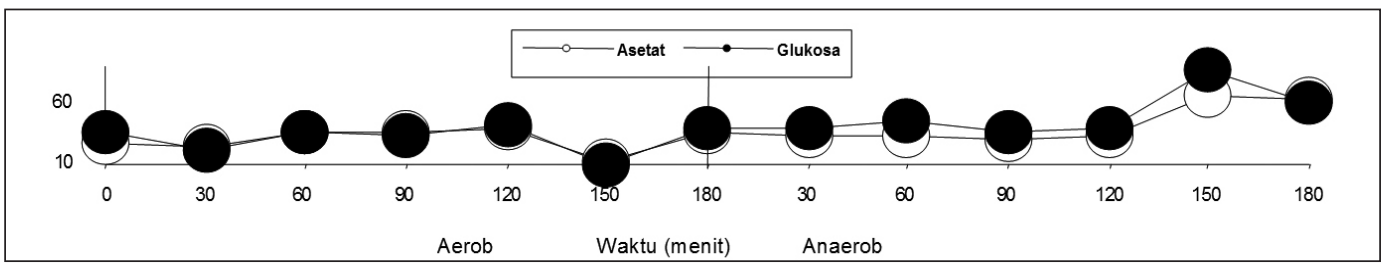

Gambar 1. Profil Perubahan amonium dalam 6 Jam Pada Kondisi aerob dan anaerob

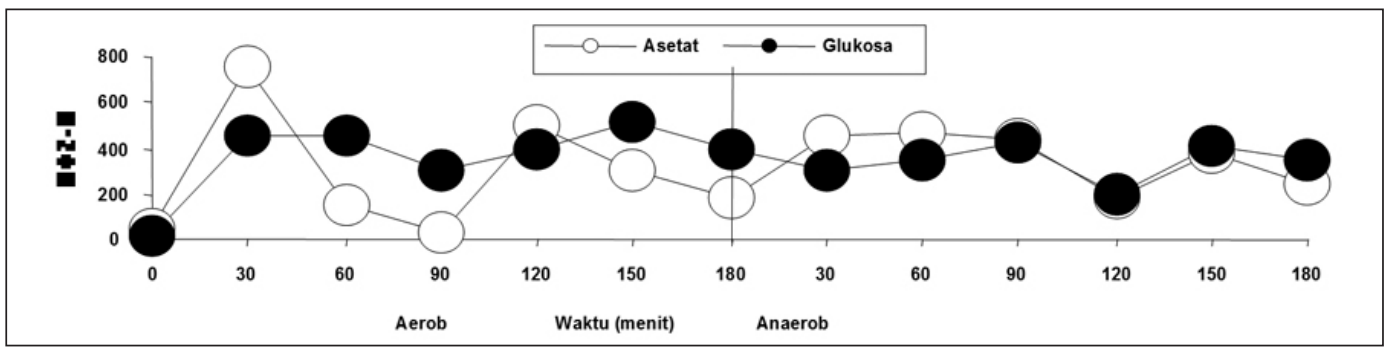

Gambar 2. Profil Nitrit Selama 6 Jam Reaksi Pada Kondisi aerob dan anaerob 


\subsection{Profil perubahan amonium}

Perubahan amonium (gambar 1) menunjukkan bahwa baik pada saat anaerob dan aerob ada fluktuasi yang agak berbeda. Pada saat akhir fase anaerob amonium turun drastis sampai mencapai $71.09 \%$ (sumber C glukosa = percobaan 1) dan $62.22 \%$ (sumber $\mathrm{C}$ asetat= percobaan 2). Pada 3 jam reaksi amonium mulai meningkat sampai akhir fase aerobik (5 jam reaksi) konsentrasi ammonium hingga mencapai 97,582 mg/L (percobaan 1) dan 73,338 mg/L (percobaan 2). Naiknya amonium kemungkinan terjadi karena pengaruh pertumbuhan bakteri filamentus ${ }^{6)}$

Jadi dapat disimpulkan sementara bahwa penambahan nutrient glukosa maupun asetat tidak memberikan pengaruh yang nyata pada proses degradasi amonium, karena keduanya mempunyai pola yang relatif sama ini sesuai dengan pernyataan ${ }^{7 \text { ) }}$ 8). Pada SBR yang dicoba pada penelitian ini lumpur efektif menyerap glukosa dan asetat pada konsidi anaerobik. Ada dua komunitas mikroba yang mampu menggunakan senyawa organik pada kondidi anaerobik di dalam unit pengolah limbah yaitu kelompok mikroba MPF dan kelompok mikroba pengakumulasi glikogen ${ }^{9)}{ }^{10)}$

\subsection{Profil perubahan nitrit}

Pada profil nitrit dapat dilihat pada gambar 2. Nampaknya profil nitrit agak berbeda antara penambahan glukosa dan asetat, pada percobaan 1 (glukosa) terjadi fluktuasi yang tidak terlalu tinggi, sedangkan pada percobaan 2 terjadi fluktuasi yang relatif tinggi, terutama saat fase anaerobik. Pada percobaan 1 produksi nitrit hampir stabil dari mulai setengah jam reaksi sampai akhir fase aerobik. Produksi nitrit terbesar dicapai pada saat 2,5 jam reaksi (518,739 mg/L) dan terendah terjadi setelah 2 jam reaksi pada fase aerobik hingga mencapai (191,743 $\mathrm{mg} / \mathrm{l}$ setara dengan $36.8 \%$ dari konsentrasi awal fase aerobik (303,435 mg/L). Pada percobaan 2 setelah setengah jam reaksi produksi nitrit sangat tinggi $(755,431 \mathrm{mg} / \mathrm{L})$, dan pada 1,5 jam reaksi produksi nitrit turun sampai mencapai $23.017 \mathrm{mg} / \mathrm{L}$. Tingginya produksi nitrit hingga mencapai $(755,431 \mathrm{mg} / \mathrm{L})$ saat fase anaerobic mungkin disebabkan oleh dominansi bakteri yang hanya mampu mereduksi nitrat menjadi nitrit saja tapi tidak diikuti oleh keberadaan bakteri yang mampu mereduksi nitrit menjadi gas nitrogen ${ }^{1)}$. Dan setelah 1,5 jam reaksi keberadaan bakteri pereduksi nitrit semakin dominan sehingga konsentrasi nitrit menjadi turun hingga 96,95\%, tetapi keberadaan bakteri tersebut tidak stabil.

\subsection{Profil perubahan nitrat}

Pada gambar 3 profil perubahan nitrat antara percobaan 1 dan 2 mempunyai fluktuasi yang sama baik pada fase anaerobic maupun aerobik. Produksi nitrat tertinggi dicapai pada saat akhir dari fase anaerobic (setelah 3 jam reaksi. Pada awal fase aerobik produksi nitrat turun hingga mencapai 49,21\% (percobaan 1) dan $60,87 \%$ (percobaan 2). Pada fase aerobik produksi nitrat relatif stabil berkisar antara $(51,033-61,582) \mathrm{mg} / \mathrm{L}$ pada percobaan 1 dan $(45,165-79,919) \mathrm{mg} / \mathrm{L}$.

3.5. Perubahan amonium, nitrit dan nitrat (tabel 2) 6 jam reaksi dapat dilihat pada tabel 2. Perubahan amonium pada percobaan 3 (penambahan glukosa) dan percobaan 4 (penambahan sukrosa) menunjukkan perubahan yang agak berbeda. Pada percobaan 3 , konsentrasi amonium dari awal fase anaerob trit dan sampai akhir reaksi menunjukkan kenaikkan dan mencapai optimal pada 2 jam reaksi pada fase aerob (berkisar dari 33,655 - 140,933 mg/L), dengan kenaikkan sekitar $20 \mathrm{mg} / \mathrm{L}$ setiap setengah jam reaksi. Sedangkan pada percobaan 4 konsentrasi amonium terlihat stabil dari awal fase anaerob sampai akhir fase 
aerob dengan fluktuasi yang sangat kecil. Produksi nitrit dan nitrat baik pada percobaan 3 dan 4 amat kecil, produksi nitrit tertinggi didapatkan pada awal fase anaerob.

Profil perubahan amonium, nitrit dan nitrat dari PDAM Surabaya dinyatakan pada gambar 4. Pada gambar 4 profil perubahan amonium terus naik dari saat awal fase anaerob sampai akhir fase anaerobik bahkan sampai fase aerob dan mencapai puncak setelah 2 jam reaksi. Produksi nitrit dan nitrat sangat kecil dan stabil dari awal fase anaerob sampai akhir fase aerob. Bila dibandingkan dengan hasil percobaan curah dari PDAM Bogor maka profil perubahan ammonium, nitrit dan nitrat sangat berbeda pada PDAM Bogor produksi nitrit dan nitrat sangat tinggi sedangkan PDAM Surabaya sangat rendah padahal sumber $\mathrm{C}$ yang diberikan adalah sama yaitu glukosa. Perbedaan ini terjadi mungkin lebih disebabkan karena bakteri yang berperan didalam proses tersebut. Pada PDAM Bogor bakteri nitrifier lebih aktif terbukti produksi nitrat dan nitrit tinggi, sedangkan PDAM Surabaya bakteri tersebut tidak berperan sehingga hampir tidak terbentuk produksi nitrit dan nitrat.

Gambar 5 menunjukkan perubahan amonium, nitrit dan nitrat dengan asupan sukrosa sebagai sumber C. Perubahan konsentrasi amonium pada awal fase anaerob sampai akhir fase terus meningkat, pada fase aerob hampir stabil dengan fluktuasi yang tidak terlalu tinggi. Fluktuasi yang agak tajam terlihat pada perubahan

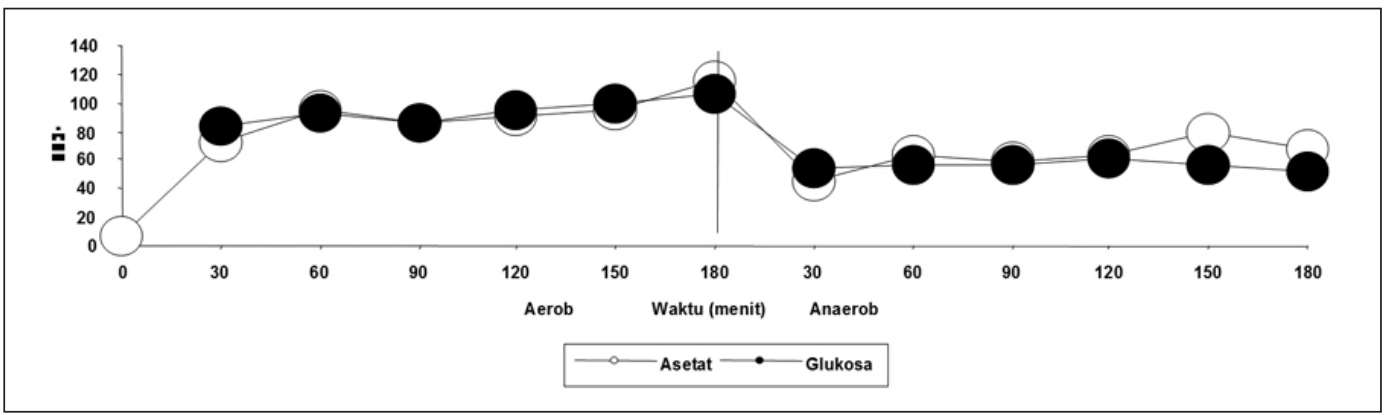

Gambar 3. Profil Nitrat Selama 6 Jam Reaksi Pada Kondisi aerob dan anaerob

Tabel 2. Produksi nitrat, nitrit dan amonium dalam batch reaktor dengan percobaan curah selama 6 jam reaksi dengan sumber karbon $(C)$ utama glukosa dan sukrosa dari limbah PDAM Surabaya

\begin{tabular}{|l|l|l|l|l|l|l|l|}
\hline Waktu (mnt) & \multicolumn{2}{|c|}{ Ammonium } & \multicolumn{2}{c|}{ Nitrit } & \multicolumn{2}{c|}{ Nitrat } & pH \\
\hline & Sukrosa* $^{*}$ & Glukosa** & Sukrosa $^{*}$ & Glukosa $^{* *}$ & Sukrosa $^{*}$ & Glukosa** $^{*}$ & \\
\hline 0 & 5.793 & 33.655 & 20.328 & 56.783 & 9.303 & 4.915 & 5.513 \\
\hline 30 & 1.803 & 30.253 & 2.077 & 1.935 & 20.696 & 3.143 & 5.434 \\
\hline 60 & 2.937 & 40.697 & 1.697 & 2.268 & 9.725 & 1.624 & 5.571 \\
\hline 90 & 3.194 & 45.848 & 0.019 & 0.129 & 16.561 & 2.805 & 5.667 \\
\hline 120 & 4.922 & 61.727 & 1.46 & 2.458 & 15.886 & 1.371 & 5.626 \\
\hline 150 & 8.419 & 69.267 & 2.125 & 1.698 & 10.147 & 1.286 & 5.344 \\
\hline 180 & 13.166 & 87.679 & 2.41 & 1.887 & 9.725 & 1.877 & 5.821 \\
\hline 30 & 11.444 & 100.007 & 1.079 & 2.268 & 15.042 & 1.962 & 6.003 \\
\hline 60 & 12.153 & 84.742 & 1.65 & 2.458 & & & 6.461 \\
\hline 90 & 8.419 & 115.224 & 1.65 & 1.317 & 13.016 & 2.046 & 6.387 \\
\hline 120 & 7.947 & 140.933 & 1.079 & 2.22 & 9.136 & 3.312 & 6.454 \\
\hline 150 & 9.742 & 87.909 & 1.317 & 2.78 & 25.506 & 4.578 & 6.592 \\
\hline 180 & 11.168 & 97.833 & 1.222 & 1.602 & 8.544 & 4.746 & 6.409 \\
\hline
\end{tabular}

* $($ percobaan 4$){ }^{* *}($ percobaan 3$)$ 
nitrat dari awal reaksi sampai akhir selama 6 jam mengalami grafik yang naik turun dan mencapai puncak pada 2,5 jam reaksi pada fase aerob. Produksi nitrit turun drastis pada awal reaksi kemudian stabil dan setelah itu itu cenderung menurun sampai akhir reaksi

\section{KESIMPULAN}

Dari percobaan ini dapat disimpulkan :

1. Pada saat anaerob proses denitrifikasi dengan sumber C utama glukosa (percobaan 1) dan asetat (percobaan 2) dari PDAM Bogor berjalan tidak stabil, dan terjadi akumulasi nitrit pada 2,5 jam reaksi sampai mencapai 518,739 $\mathrm{mg} / \mathrm{l}$. Penambahan nutrient glukosa maupun asetat tidak memberikan pengaruh yang nyata pada proses degradasi amonium, karena keduanya mempunyai pola yang relatif sama.

2. Perubahan amonium pada percobaan 3 (penambahan glukosa) dan percobaan 4 (penambahan sukrosa) dari PDAM
Surabaya menunjukkan perubahan yang agak berbeda. Pada percobaan 3 , konsentrasi amonium dari awal fase anaerob sampai akhir reaksi menunjukkan kenaikkan dan mencapai optimal pada 2 jam reaksi pada fase aerob (berkisar dari 33,655 - 140,933 $\mathrm{mg} / \mathrm{L}$ ), dengan kenaikkan sekitar 20 $\mathrm{mg} / \mathrm{L}$ setiap setengah jam reaksi.

\section{UCAPAN TERIMAKASIH}

Penulis mengucapkan terimakasih kepada Proyek Penelitian Sumber Daya Hayati Puslit-Biologi yang telah memberi dana untuk penelitian ini, juga kepada teman-teman kerja yang telah membantu dalam penelitian ini.

\section{DAFTAR PUSTAKA}

1. Ruiz G, Jeison D, Chamy R. 2003. Nitrification with high nitrite accumulation for the treatment of waste water with high ammonia concentration. Water Res 37 : 1371-1377

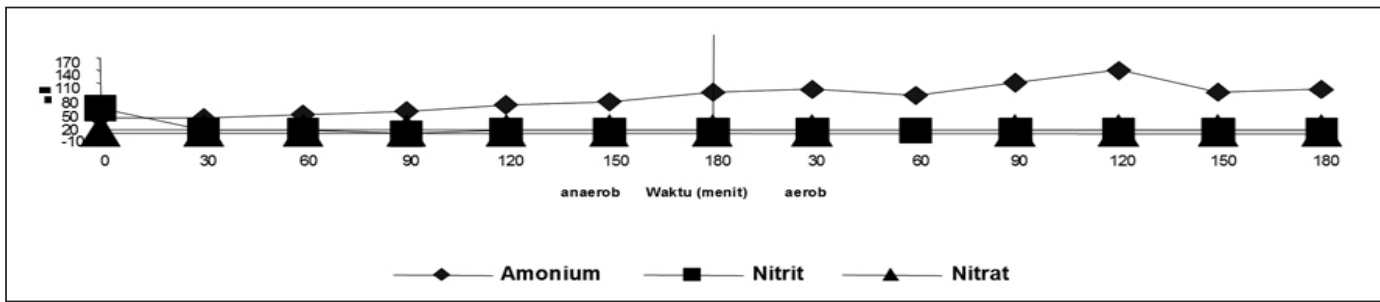

Gambar 4. Profil Perubahan amonium, Nitrit dan Nitrat pada Percobaan Curah dari PDAM Surabaya (Glukosa)

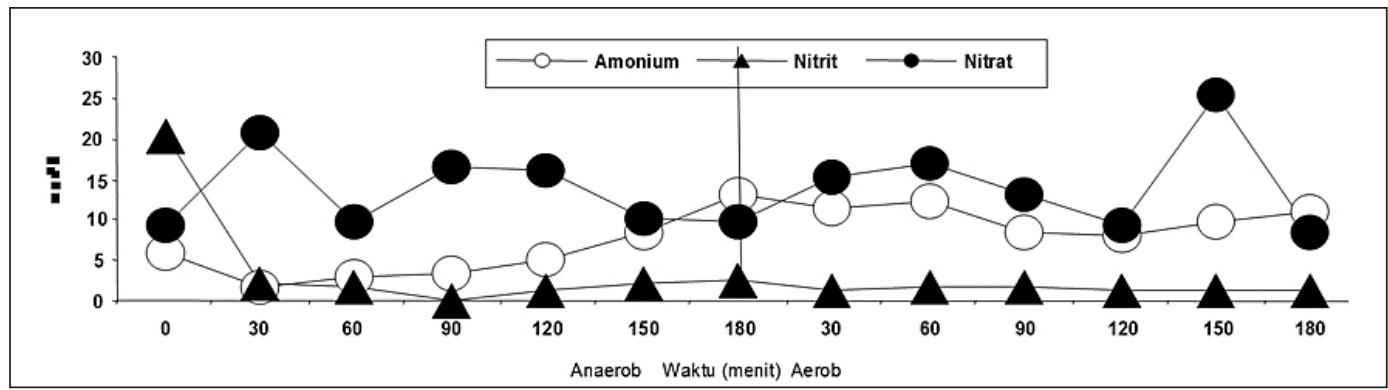

Gambar 5. Profil Perubahan amonium, Nitrit dan Nitrat pada Percobaan Curah Selama 6 Jam Reaksi dari PDAM Surabaya (Sukrosa) 
2 Anthonisen A.C., Lohr R.C., Prakasam T.B.S. and Srinath E.G., 1976. Inhibition of nitrification by ammonia and nitrous acid. J.Wat Pollut.Cont.Fed. 48 : 835852

3. Bovell, C. 1967. The effect of sodium nitrite on the growth of Micrococcus denitrificans Arch.Microbiol. 59:13-19

4. Focht D.D. and Verstraete W., 1977. . Plenum Press. New York.Wastewater, Microb. Ecal., pp ;119- 138

5. Hong W. Zhao, D.S. Mavinic, W.K.Oldham and FredericA.Koch, 1999. Controlling Factors for Simultaneous Nitrification and Denitrification in a Twostage Intermittent Aeration Process Treating Domestic Sewage. Wat. Res. Vol 33 (40) : 961-970

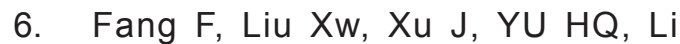
YM. 2009. Formation of aerobic granules and their $\mathrm{PHB}$ production at varoius substrate and ammonium concentrations. Biosenresour Technol 34 : 421-428.

7. Cech, JS, and P hHatman. 1990. Glucose Induced Breakdon of Enhanced Biological Phosphorus Removal, Environ. Tech., Vol. 11, pp: 651-656.
8. Mino, T., V Arun, Y. Tsuzuki, T. Matsuo, 1987, Effect of Phosphorus Accumulacion on Acetate Metabolim in Biological Phosphorus Removal Process, Wat. Sci. Tech., 23, pp: 567576

9. Kortstee, G. J. J., K. J. Appledoorn, C. F. C. Bonting, E. W. J. v. Niel and H. W. v. Veen, 1994 Biology of Polyp - Accumulating Bacteria Involved in Enhanced Biological Phosphorus Removal, FEMS Microbiol., Rev. 15, pp : 137-153

10. Lotter, L. H. and M. Murphy, 1998, Microscopic Evaluation of Carbon and Phosphorus Accumulacion in Nutrient Removal Activated Sludge Plants, Wat. Sci. Tech., Vol. 20, No.4/5, IAWPRC, Great Britain, pp : 37- 49

11. Jenkins, D. and V. Tandoi 1991, The Applied Microbiologi of Enhanced Biological Phosphate Removal Accomplishmen and Needs, Wat. Res., Vol. 25, No.12,Pergamon Press plc, Great Britain, pp: 1471- 1478 